\title{
Climate-Driven Changes in Lake Areas for the Last Half Century in the Valley of Lakes, Govi Region, Southern Mongolia
}

\author{
Alexander Orkhonselenge ${ }^{1}$, Goro Komatsu ${ }^{2}$, Munkhjargal Uuganzaya ${ }^{1}$ \\ ${ }^{1}$ Laboratory of Geochemistry \& Geomorphology, National University of Mongolia, Ulaanbaatar, Mongolia; \\ ${ }^{2}$ International Research School of Planetary Sciences, Università d'Annunzio, Pescara, Italy
}

Correspondence to: Alexander Orkhonselenge, rkhnslng@num.edu.mn

Keywords: Lakes, Lake Areas, Climate Change, Govi Region, Southern Mongolia

Received: May 15, $2018 \quad$ Accepted: July 23, $2018 \quad$ Published: July 26, 2018

Copyright (C 2018 by authors and Scientific Research Publishing Inc.

This work is licensed under the Creative Commons Attribution International License (CC BY 4.0).

http://creativecommons.org/licenses/by/4.0/

\section{c) (i) Open Access}

\section{ABSTRACT}

This study presents the changes in lake areas in the Valley of Lakes, the Govi region, southern Mongolia. The recent changes in lake areas show decreases depending on vulnerability of lake basins and response of Govi landscape to the present climatic warming. During the recent 44 - 45 years (from 1970 to 2014 or 2015), modern lakes have encountered the present rapid increase in temperature, water evaporation and drying up that induced the reduction in lake areas in the Valley of Lakes. The finding of the reduction in lake areas is consistent with the trends on increasing in temperature since 1995 and fluctuating precipitation since 1975. Investigations with detailed chronology of lake sediment are needed from the lakes to review a more complete evolution of lake basins during the Late Quaternary paleoclimatic history in Mongolia and Central Asia.

\section{INTRODUCTION}

Mongolia is located in the center of the Eurasian Continent, and hosts the Siberian-Mongolian winter anticyclone, which interacts with westerlies and winter monsoon atmospheric circulations. Because of its geographical position at the junction of these three large-scale climatic systems, Mongolia is considered to play an important role in the climate system of Central Asia. Arid and semi-arid Asia, including semi-arid Mongolia, represents one of the areas, most sensitive to large-scale climatic changes [1-3]. In other words, Mongolia has an extremely dry extra-continental climate developing under the interaction of the Siberian high- and Asian low-pressure cells, and the westerlies [4-6], which is modulated by the North Atlantic Oscillations (NAO) [7]. Mongolia raises a particular interest as a valuable record of climatic and environmental changes in Central Asia due to highly elevated intercontinental location on the Central Asia collision belt occupying a transitional area between Siberian taiga forest in the north and Govi (Gobi) ${ }^{\star 1}$ desert in the south, where the Mongolian High Pressure System develops over the region [8].

"Govi" has been often spelled as "Gobi" in the international literature. Govi is a correct English translation from Mongolian "Говь". 
Lakes can be taken as an indicator of changing climate and increase or shrinkage in response to the changing climate [e.g., 9, 10]. Lake area is an important indicator for climate change and its relationship with climatic factors is critical for understanding the mechanisms that control lake level changes [11]. Understanding geomorphic evolution of lacustrine landscape and estimating the changes in lake areas in southern Mongolia are important because of its contribution to review the paleo and modern climatic and environmental history in Mongolia and Central Asia. However, despite the importance of paleoclimatic and paleoenvironmental changes in Mongolian lakes for our understanding of large-scale regional changes [e.g., 10, 1-20], the temporal analysis for modern lakes in Mongolia itself has rarely been conducted. This study considers the recent changes in lake areas for six lakes (Table 1) in the Valley of Lakes, Govi region, southern Mongolia (Figure 1, Figure 2).

To date, studies on modern lakes in Mongolia have only been focused on their origin, lake level fluctuations, morphometric evolution of lake basins and chemical composition of lake water [21, 22], and not on important trends for the lake area. In 1926, Smirnov hypothesized that Lakes Uvs, Khyargas, Airag, Sangiin Dalai, Khar, Durgun, Tsookhor and Uureg in western Mongolia were contained in a large lake basin covering an area of about 50,000 $\mathrm{km}^{2}$ [21]. In 1940-1944, Murzaev noted that in the Mesozoic Period, the lacustrine landscape dominated in Mongolia and identified that lake level fluctuations for most lakes in Mongolia were caused by evaporation and erosion [21]. In 1951-1953, Tsegmid stated that lakes in the Valley of Lakes were standing at $40-45 \mathrm{~m}$ higher than present or at $1380 \mathrm{~m}$ a.s.l. based on paleoshorelines and paleoterraces [21]. Since 1962, Institute of Geography and Permafrost studied physical and chemical characteristics of all lakes in Mongolia including temperature, depth, minerals, etc. of lake water [21]. Komatsu et al. [10] reconstructed stable paleolakes for extended periods including basins of Lakes Buun Tsagaan, Tsagaan (or Adgiin Tsagaan) and Orog in the Valley of Lakes in southern Mongolia, covering extensive areas of the valley floor based on identified shorelines at different elevations using satellite radar remote sensing images and field data. Davaa [23] presented changes in water resources including flow of rivers, lake levels and the size of glaciers in Mongolia based on field-monitoring data, hydrological analyses utilizing GIS and remote sensing data. Kang et al. [11] investigated lake area changes and their relations to precipitation for 165 lakes in different regions of Mongolia based on a linear regression analysis. Szumińska [24] analyzed changes in surface area of Lakes Buun Tsagaan and Orog during the last 40 years in the context of water storage and in relation to climate conditions (air temperature, precipitation and

Table 1. Morphometric value for the selected lakes in the Govi region, southern Mongolia modified from [21].

\begin{tabular}{|c|c|c|c|c|c|c|}
\hline No. & Lakes & $\begin{array}{l}\text { Altitude } \\
\text { (m a.s.l) }\end{array}$ & Depth (m) & Length $(\mathrm{km})$ & Width (km) & Shoreline $(\mathrm{km})$ \\
\hline 1 & Lake Ulaan & 1008 & $\begin{array}{l}0.9 \\
1.6^{1}\end{array}$ & 45.0 & $\begin{array}{l}29.0 \\
40.0^{1}\end{array}$ & 87.0 \\
\hline 2 & $\begin{array}{c}\text { Lake Taatsiin } \\
\text { Tsagaan }\end{array}$ & 1234 & $\begin{array}{l}2.0 \\
2.3^{1}\end{array}$ & 4.1 & $\begin{array}{l}2.0 \\
3.5^{1}\end{array}$ & 11.8 \\
\hline 3 & Lake Orog & 1217 & $\begin{array}{l}3.0 \\
6.3^{1}\end{array}$ & 31.8 & $\begin{array}{c}2.0 \\
7.7^{1}\end{array}$ & 75.0 \\
\hline 4 & Lake Buun Tsagaan & 1312 & $\begin{array}{c}9.5 \\
16.0^{1}\end{array}$ & 23.5 & $\begin{array}{l}11.0 \\
19.0^{1}\end{array}$ & 81.0 \\
\hline 5 & Lake Biger & 1287 & $\begin{array}{l}0.9 \\
2.0^{1}\end{array}$ & 5.7 & $\begin{array}{l}1.2 \\
2.3^{1}\end{array}$ & 13.8 \\
\hline 6 & $\begin{array}{c}\text { Lake Shargiin } \\
\text { Tsagaan }\end{array}$ & 964 & $\begin{array}{l}0.5 \\
1.3^{1}\end{array}$ & 5.0 & $\begin{array}{c}3.0 \\
4.8^{1}\end{array}$ & 16.2 \\
\hline
\end{tabular}

${ }^{1}$ Maximum value. 


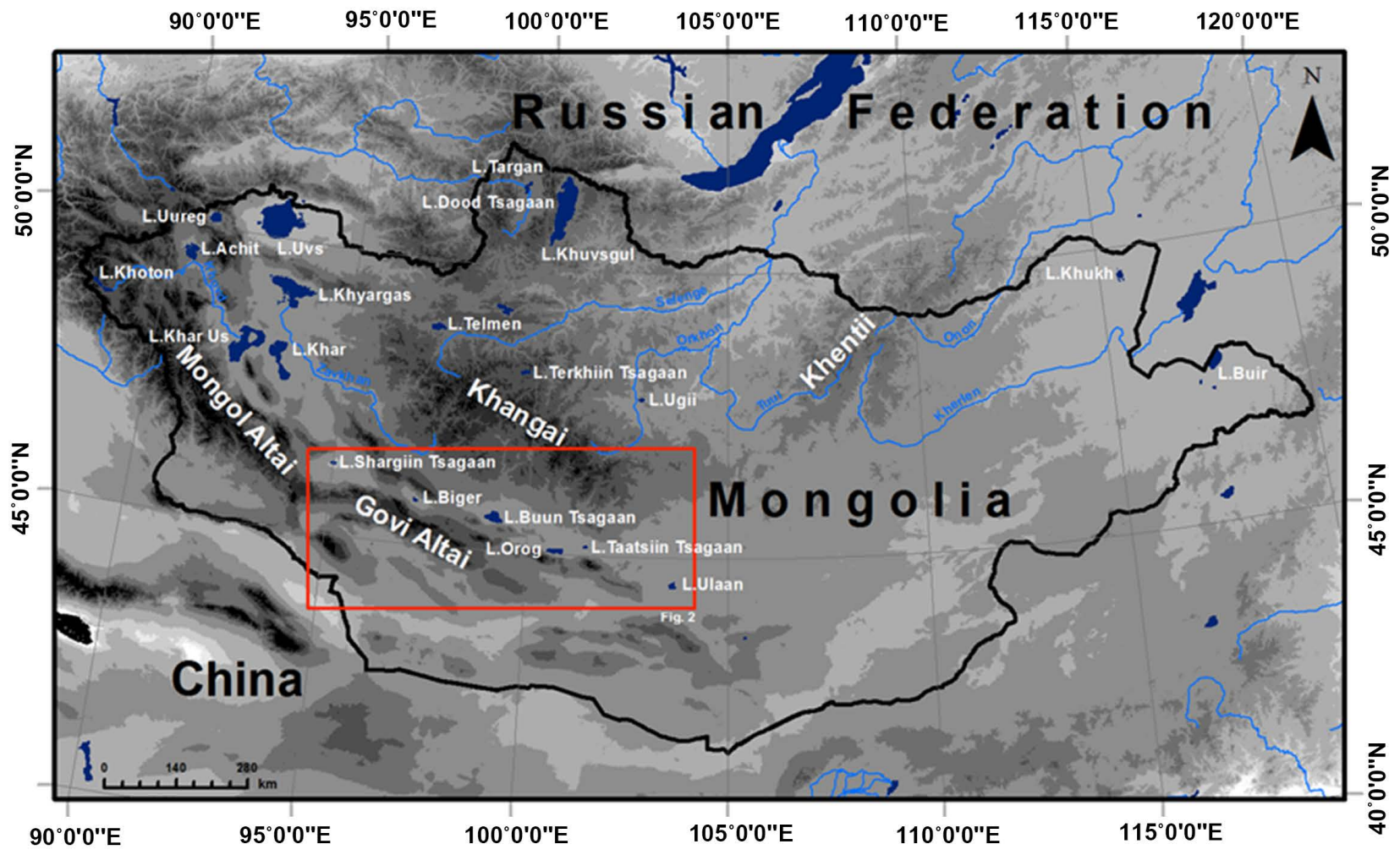

Figure 1. Geographical location of the selected lakes in Mongolia. The base map is a digital elevation map (DEM) derived from a terrain's elevation data.

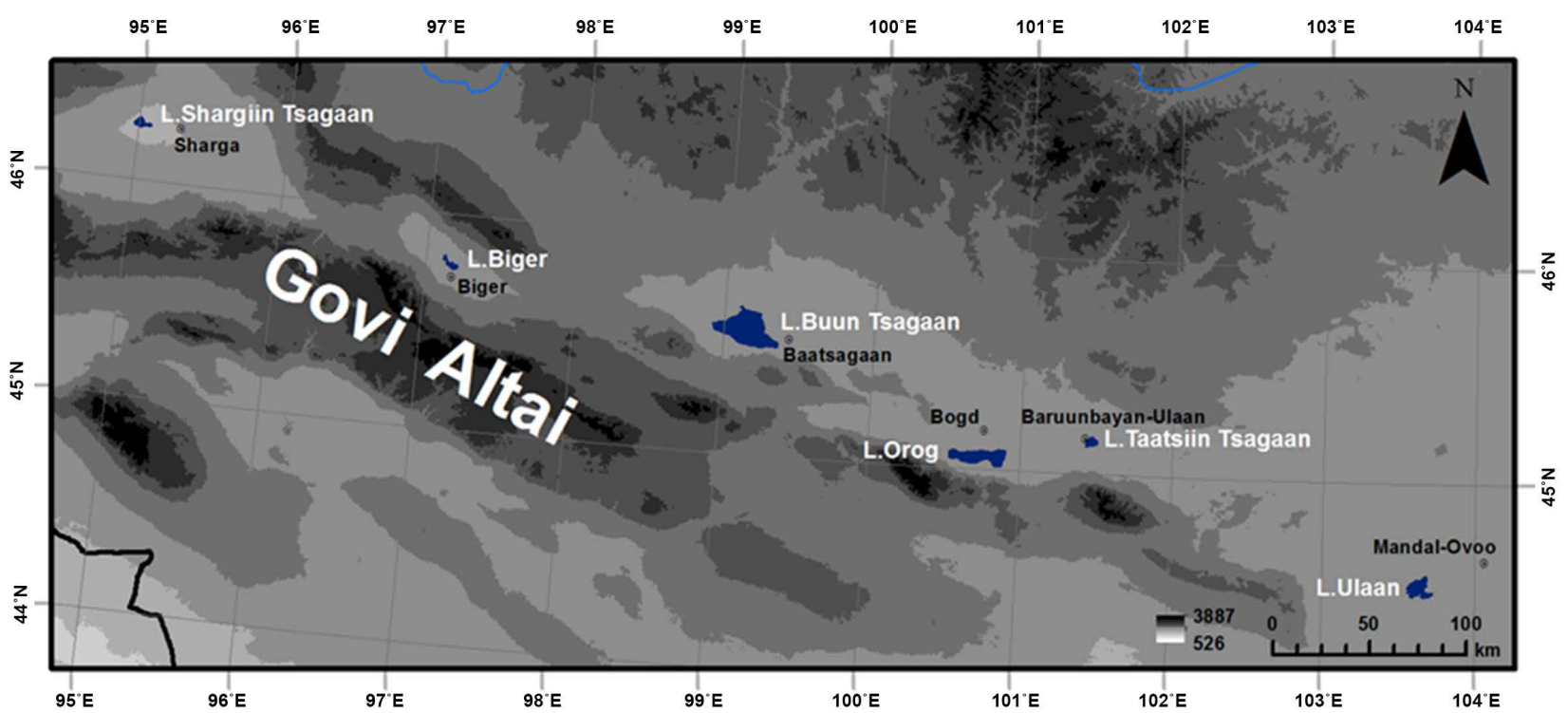

Figure 2. Topography of the selected lakes in southern Mongolia: Lakes Ulaan, Taatsiin Tsagaan, Orog, Buun Tsagaan, Biger, and Shargiin Tsagaan.

snow cover) and permafrost degradation based on satellite images, the NOAA climate data and CRU dataset. Kang \& Hong [25] estimated lake surface areas for selected 73 lakes greater than $6.25 \mathrm{~km}^{2}$ within Mongolia during 2000-2011 using the minimum composite NDVI (Normalized Difference Vegetation Index) from MODIS (Moderate Resolution Imaging Spectroradiometer), and found the slight-to-moderate 
lake area reductions in semi-arid regions and rapid lake area reductions in arid regions.

The estimation of lake areas for modern lake is a key to characterize the local climate change within lake basins. Such a study contributes to understanding the impacts of climate changes on the hydrological regime in a region. Because climate change is the major driving force resulting in the environmental changes in lake basins [e.g., 26, 27], interpreting sequences of lacustrine sediments are important for understanding the climatic changes and landscape evolution in the lake basins. However, remote sensing assessments of lake area expansion and shrinkage provide another proxy for inferring such environmental changes. In this study, we estimated lake areas for the six lakes (Figure 1, Table 1) using Landsat 8 images in 2014-2015 and topographical map in 1970. This study provides the new result in estimation of lake areas during the 44 or 45 years for the lakes in the Valley of Lakes, Govi region, southern Mongolia.

\section{STUDY AREAS}

\subsection{Lake Ulaan}

Lake Ulaan is located in the southeastern most tip of the Valley of Lakes between the Khangai and Govi Altai Mountain Ranges (Figure 1, Figure 2). The morphometric values including altitude, width, length, depth and shoreline are presented in Table 1. Because the Govi sediment filled in the lake basin radiates red ray from the water surface, the lake was named Ulaan meaning red [21]. The Ongi River draining the Khangai Mountain Range flows into Lake Ulaan, but the river cannot permanently feed the lake today, therefore depth and area of the lake are unstable. There is a record noting that the lake was almost completely dried out in 1952-1953, the lake bottom exposed, and salt marshes were bleached on the bottom [21]. In the lake, thick alluvial and lacustrine sediments deposited during the past [21]. The lake level is strongly dependent on precipitation, i.e., the lake water covers a large area from more than ten to more than hundred sq. $\mathrm{km}$ during heavy rainfall and is almost dried out during low precipitation. This phenomenon implies the shallowness and flat bottom of the lake [21]. Shores are mostly in plains and there are sandy beach ridges located on the northern and northwestern margins of the lake. During torrential rains, flash floods transport the sands and gravels into the lake along the Ongi River and some other branch mountains. The lake sediments consist of mud and sand.

\subsection{Lake Taatsiin Tsagaan}

Lake Taatsiin Tsagaan is located in the Valley of Lakes between the Khangai and Govi Altai Mountain Ranges (Figure 1, Figure 2). The morphometric values including altitude, width, length, depth and shoreline are presented in Table 1 . The lake is fed by rainfall, overflow and ground water. During the heavy rainfall, the Taats River draining the Khangai Mountain Range flows into the lake.

\subsection{Lake Orog}

Lake Orog is located extending from west to east in the Valley of Lakes between the Khangai and Govi Altai Mountain Ranges (Figure 1, Figure 2). The morphometric values including altitude, width, length, depth and shoreline are presented in Table 1. In the lake basin there are numerous bays and estuaries, and its shores are relatively flat plains [21]. In the north of the lake, a crescent sand dune field extends for more than $10 \mathrm{~km}$ long, $1.0-1.5 \mathrm{~km}$ wide, and it is $20-50 \mathrm{~m}$ higher than the lake level. The beach ridges (10 - $15 \mathrm{~m}$ high) around the lake imply that the lake level repeatedly fluctuated in the past due to shallowness, high evaporation of lake water and annually oscillating overflow [21].

According to Pevtsov (1878-1879), Lake Orog was contained in a large paleolake basin between the Khangai and Govi Altai Mountain Ranges, and widely distributed lake deposits imply that a large fraction of the Mongolian Govi was a bottom of the large lake [21]. The altitudes of the paleostrandlines in the east and west of modern Lake Orog are probably lower than $1250 \mathrm{~m}$ a.s.l., and the level of the present-day lake lies at $1210-1220 \mathrm{~m}$ a.s.l. [10]. The lake bottom is divided into two parts, and the bottom in the west of the lake is deeper and larger than that in the east [21]. Lake deposits consist of mud, clay and sand. Main 
sources of the lake water are precipitation, overflow and ground water. The Tuin River draining the Khangai Mountain Range flows into the lake and there are abundant marshes along the Tuin River and other small rivers flowing into the lake. Due to the lack of outflow, lake water is saline.

\subsection{Lake Buun Tsagaan}

Lake Buun Tsagaan is located in the Valley of Lakes between Khangai and Govi Altai Mountain Ranges (Figure 1, Figure 2). The morphometric values including altitude, width, length, depth and shoreline are presented in Table 1. The southern and northern margins of the lake border with the Khoid Tal, a wide plain and the Khar Argalant Mountain Range, a branch of Govi Altai Mountain Range, respectively [21]. Beach ridges are found along the northern and eastern shorelines, and a distance between these beach ridges ranges from 40 - $50 \mathrm{~m}$ to 200 - $250 \mathrm{~m}$. Lacustrine deposits consist of clay, mud and sand. The Baidrag River draining the Khangai Mountain Range flows into the lake and there is no any outflow [21]. The present-day lake level is estimated to be about $1310 \mathrm{~m}$ a.s.l. [10]. The paleolake Buun Tsagaan was likely connected to the paleolake Tsagaan (or Adgiin Tsagaan), now a small ephemeral lake $60 \mathrm{~km}$ to the east, at the $1350 \mathrm{~m}$ a.s.l. during the late Quaternary Period [10]. A recent decadal rise in lake level formed numerous small lakes with the depths of $1-2 \mathrm{~m}$ and a total area of about $10 \mathrm{~km}^{2}$ [21].

\subsection{Lake Biger}

Lake Biger is located in an intermontane basin surrounded by high mountains between the Khangai and Govi Altai Mountain Ranges (Figure 1, Figure 2). The morphometric values including altitude, width, length, depth and shoreline are presented in Table 1 . The lake is a saline lake and is fed by rainfall and ground water. Numerous streams flow into the lake. Shorelines are situated on the lowlands and are abundantly covered by marshes [21].

\subsection{Lake Shargiin Tsagaan}

Lake Shargiin Tsagaan is located in a wide depression of Sharga Govi in an intermontane basin surrounded by high mountains, i.e., it is situated in the northwesternmost tip of the Valley of Lakes between the Khangai and Govi Altai Mountain Ranges (Figure 1, Figure 2). The morphometric values including altitude, width, length, depth and shoreline are presented in Table 1 . The lake is fed by rainfall and ground water, and the Bayan, Sharga and Khoid Rivers flow into the lake [21]. The lake level is unstable because the lake level highly oscillates during the heavy rainfall. Shores are swampy and marshy due to its position on lowland.

\section{METHOD}

In this study, the following procedures were taken: 1) to choose large lakes from the Govi region in southern Mongolia, 2) to estimate the lake areas in 1970 and 2014 or 2015, and 3) to evaluate changes in the lake areas. In total, six larger lakes (Table 1) were chosen from the Valley of Lakes, Govi region (Figure 1, Figure 2). In order to calculate the lake areas, 1:100 000 topographical maps (1970) and Landsat 8 images (2014/2015) are used as the primary data source for compiling on-screen digitizing of lake areas (Table 2, Figure 3). The path and row for each Landsat image are identified with the digital Geographic Information System database provided by United States Geological Survey (USGS). A layer of the satellite imagery was draped over the topographic data to indicate changes in lake areas during the past 44 or 45 years.

\section{RESULTS AND DISCUSSION}

\subsection{Changes in Lake Area for the Lakes in the Valley of Lakes}

In this study, the results from the six lakes (Table 1) from the Valley of Lakes in the Govi region (Figure 1, Figure 2) show decreases in lake areas for all lakes during the past 44 or 45 years (Table 3). 
Table 2. Information of Landsat 8 images for the selected lakes from in the Govi region, southern Mongolia.

\begin{tabular}{ccccc}
\hline No. & Lakes & Date & Path & Row \\
\hline 1 & Lake Ulaan & $\operatorname{Jun~}^{\text {th }}, 2014$ & 133 & 29 \\
2 & Lake Taatsiin Tsagaan & Jun $16^{\text {th }}, 2015$ & 134 & 29 \\
3 & Lake Orog & Oct $13^{\text {th }}, 2015$ & 135 & 29 \\
4 & Lake Buun Tsagaan & Aug $30^{\text {th }}, 2014$ & 136 & 28 \\
5 & Lake Biger & ${\operatorname{Jul~} 28^{\text {th }}, 2014}^{\text {th }}$ & 137 & 28 \\
6 & Lake Shargiin Tsagaan & May $11^{\text {th }}, 2015$ & 138 & 28 \\
\hline
\end{tabular}
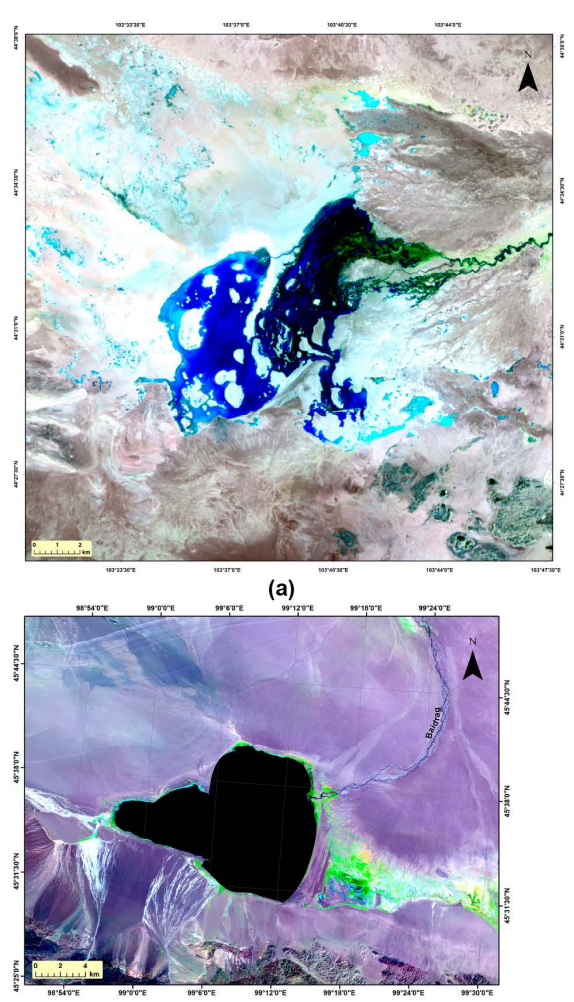

(d)

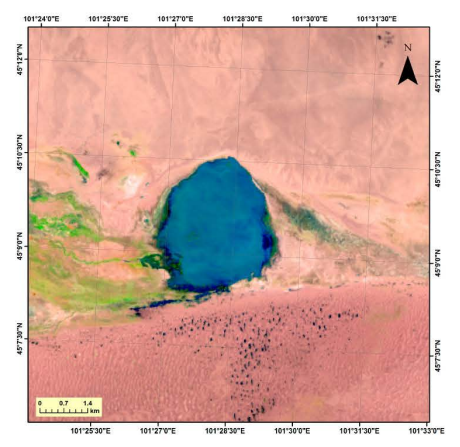

(b)

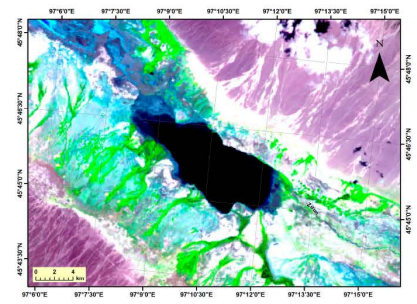

(e)

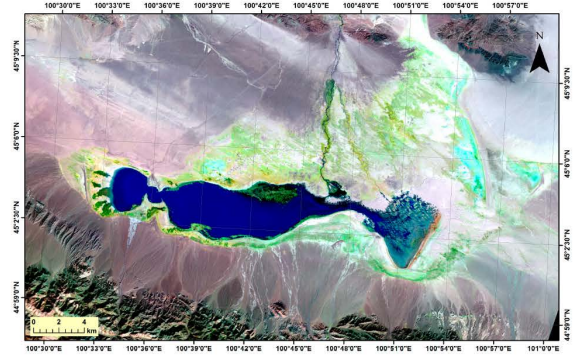

(c)

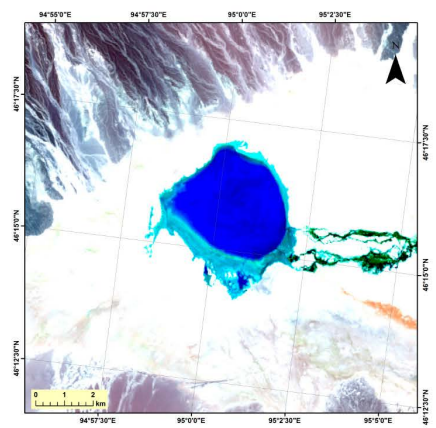

(f)

Figure 3. Landsat 8 images in 2014-2015 for the six lakes in Govi region, southern Mongolia: (a) Lake Ulaan, (b) Lake Taatsiin Tsagaan, (c) Lake Orog, (d) Lake Buun Tsagaan, (e) Lake Biger, and (f) Lake Shargiin Tsagaan.

For Lake Ulaan (Figure 3(a), Figure 4(a)), the lake area reduced by $18.2 \mathrm{~km}^{2}$ from 1970 to 2014 (Table 3). The decrease in lake area during the past 44 years may have been related to the local climate change of rising temperature since 1995 and decreasing precipitation since 1987 (MO in Figure 5) observed in the Mandal-Ovoo meteorological station (Figure 2) locating $23.1 \mathrm{~km}$ from the lake. Lake Ulaan was identified in 1991 but did not appear in the Landsat images since 2000 [11], however reappearance of Lake Ulaan was detected in Landsat 8 in 2014 (Figure 3(a)). It is shown that a gradual decrease in lake area for the Lake Ulaan started since 1987 and strengthened since 1995 (MO in Figure 5).

For Lake Taatsiin Tsagaan (Figure 3(b), Figure 4(b)), the lake area decreased by $7.9 \mathrm{~km}^{2}$ between 1970 and 2015 (Table 3). The decrease in the lake area may have been connected to the intensification of 
Table 3. Changes in lakes areas for the selected lakes from in the Govi region, southern Mongolia.

\begin{tabular}{ccccccc}
\hline \multirow{2}{*}{ No. } & \multirow{2}{*}{ Lakes } & & Area $\left(\mathrm{km}^{2}\right)$ & Volume $\left(\mathrm{km}^{3}\right)$ & \multicolumn{2}{c}{ Calculated areas $\left(\mathrm{km}^{2}\right)$} \\
\cline { 3 - 6 } & & $($ Tserensodnom, 1971) & 1970 & 2014 & 2015 \\
\hline 1 & Lake Ulaan & 175 & 0.158 & 62.38 & 44.16 & \\
2 & Lake Taatsiin Tsagaan & 9.9 & 0.011 & 18.66 & & 10.67 \\
3 & Lake Orog & 140 & 0.42 & 145.21 & & 49.65 \\
4 & Lake Buun Tsagaan & 252.1 & 2.385 & 324.29 & 241.12 & \\
5 & Lake Biger & 11.0 & 0.001 & 8.95 & 8.45 & \\
6 & Lake Shargiin Tsagaan & 15.7 & 0.008 & 16.14 & & 11.12 \\
\hline
\end{tabular}

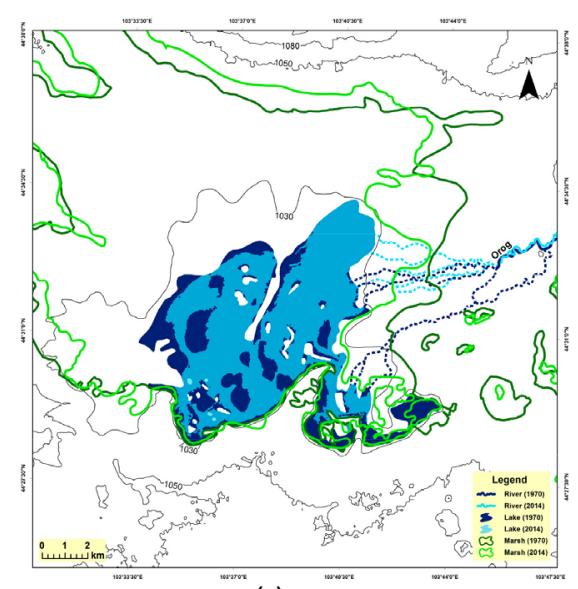

(a)

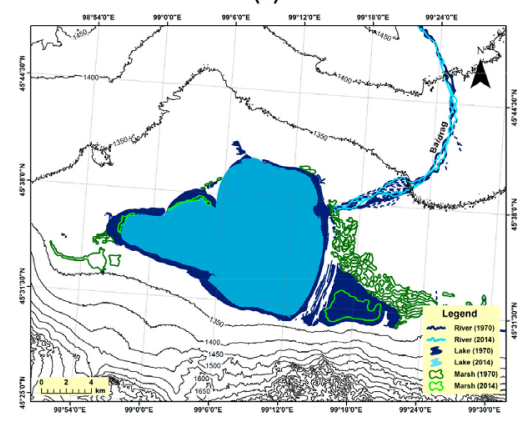

(d)

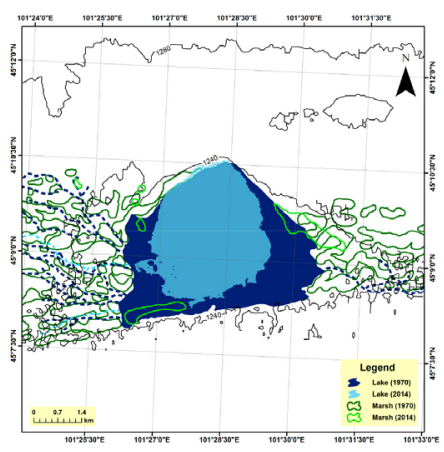

(b)

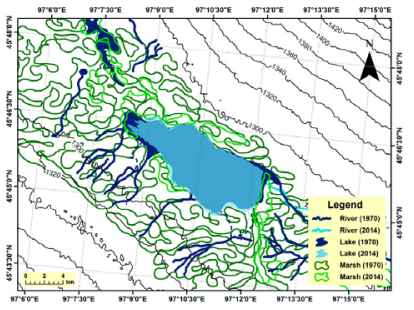

(e)

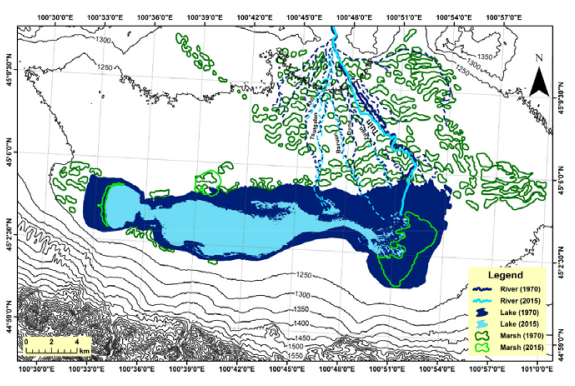

(c)

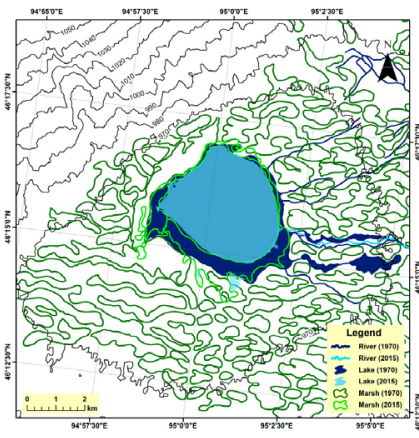

Figure 4. Changes in lakes areas for the selected lakes from in Govi region, southern Mongolia: (a) Lake Ulaan, (b) Lake Taatsiin Tsagaan, (c) Lake Orog, (d) Lake Buun Tsagaan, (e) Lake Biger, and (f) Lake Shargiin Tsagaan.

rising temperature since 1997 although precipitation increased in 1987-1997 and since 2006 (BU in Figure 5) observed at the Baruunbayan-Ulaan meteorological station (Figure 2) positioning $1.7 \mathrm{~km}$ from the lake. It is shown that the lake area is highly dependent on temperature, and not on fluctuation in the precipitation, i.e., the lake is very sensitive to the present warming.

For Lake Orog (Figure 3(c), Figure 4(c)), the lake area has decreased by $95.5 \mathrm{~km}^{2}$ from 1970 to 2015 (Table 3). This large decrease during the past 45 years may indicate that the lake is very sensitive to climate change. The local climatic data at the Bogd meteorological station (Figure 2) locating $11.6 \mathrm{~km}$ from 
Temperature anomaly $\left({ }^{\circ} \mathrm{C}\right)$

MO

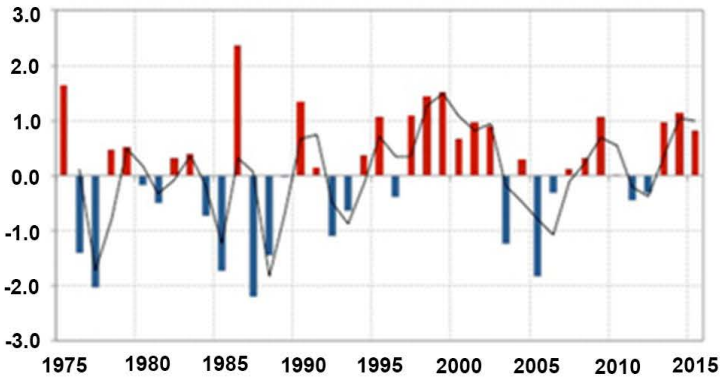

BU

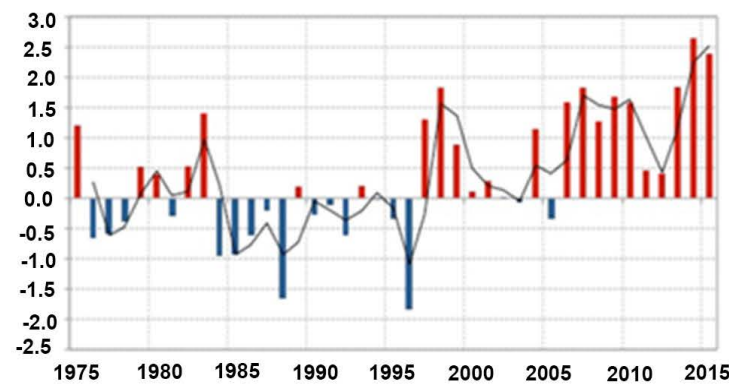

BO

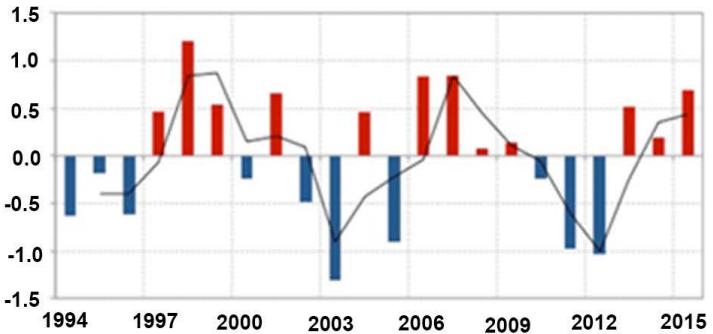

BI

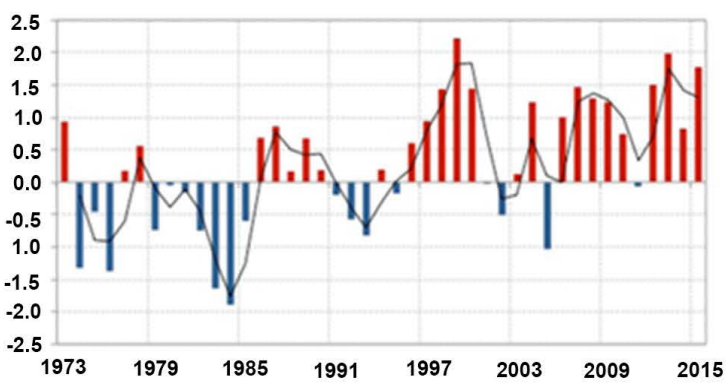

$\mathrm{SH}$

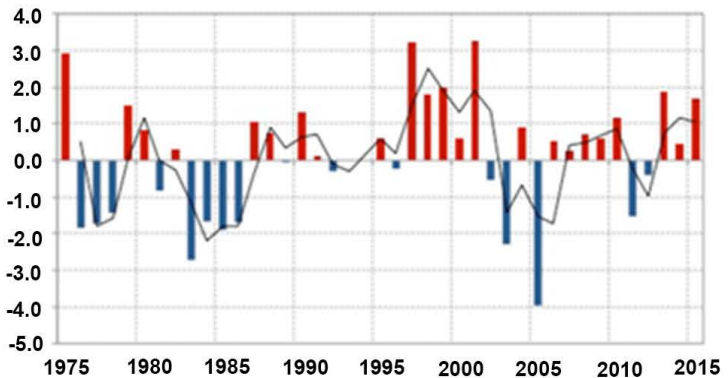

Precipitation anomaly $(\mathrm{mm})$
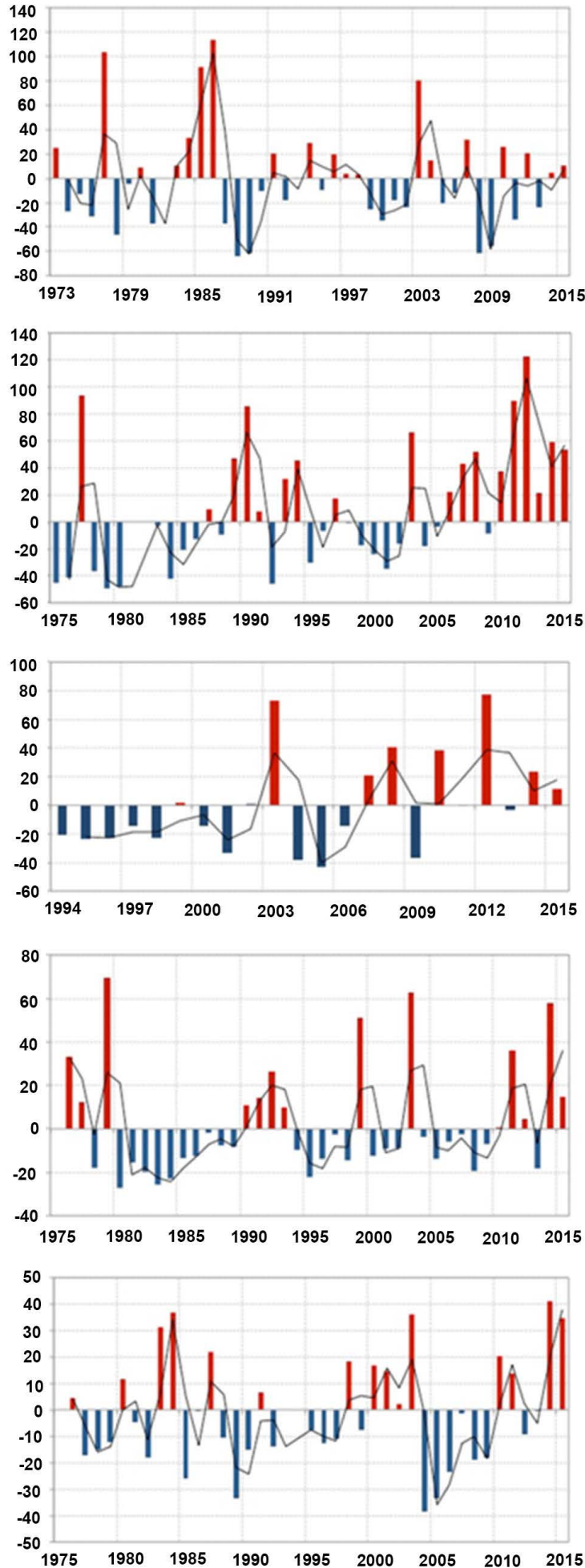

Figure 5. Anomalies of annual mean air temperature (left) and annual mean precipitation (right) at Mandal-Ovoo (MO), Baruunbayan-Ulaan (BU), Bogd (BO), Biger (BI) and Sharga (SH) meteorological stations during these years. 
the lake was found for a short-term period between 1994 and 2015. According to the data at the Bogd meteorological station, the temperature rise with fluctuations since 1997 (BO in Figure 5) may have impacted on the decrease in lake area, i.e., drought before 2003 affected the lake area although precipitation fluctuated to increase since 2003 (BO in Figure 5). The Baruunbayan-Ulaan meteorological station (Figure 2) is the next nearest one at $41.3 \mathrm{~km}$. According to the data of this last station, Lake Orog is similar to Lake Taatsiin Tsagaan, i.e., its area has been decreasing since 1997 when the temperature has been rapidly increased and the rise continues to present, although precipitation increased slightly since 2003 . This is similarly consistent with the result by [24] showing that the lake area decreased in 1986-1989 and 1998-2004, and the lake disappeared in 2004-2011.

For Lake Buun Tsagaan (Figure 3(d), Figure 4(d)), lake area reduced by $83.2 \mathrm{~km}^{2}$ between 1970 and 2014 (Table 3). The large decrease in lake area may imply a direct impact of rising temperature during the past 45 years, although there is no climatic data in the Baatsagaan meteorological station situating $0.8 \mathrm{~km}$ from the lake. Instead, the Bogd meteorological station is the nearest one situating $119 \mathrm{~km}$ from the lake. At the station, temperature and precipitation rises were observed since 1997 and 2003, respectively (BO in Figure 5). In addition, the Biger meteorological station (Figure 2) is the second one locating $138.6 \mathrm{~km}$ from the lake. According to the data at the Biger meteorological station, continuous rise in temperature and intermittent fall in precipitation were observed since 1980 and 1987 (BI in Figure 5), respectively. The large decrease in lake area may have been started since 1987 and strengthened since 1997. This is similarly consistent with the result by [24] who showed that the lake area decreased in 1987-1991 and since 1995. The large loss in the lake occurred in the eastern part and it has been also confirmed by [24] indicating that after 1996, the water diminished until the eastern part disappeared entirely.

For Lake Biger (Figure 3(e), Figure 4(e)), the lake area reduced by $0.5 \mathrm{~km}^{2}$ between 1970 and 2014 (Table 3). The small decrease in lake area shows that Lake Biger is similar to other lakes in the Valley of Lakes being affected by the rising temperature since 1987 and decreasing precipitation since 1980 (BI in Figure 5) observed in the Biger meteorological station (Figure 2) locating at $3.3 \mathrm{~km}$ from the lake. The data shows that decrease in lake area may have started since 1980 and strengthened since 1996 (BI in Figure 5). It is implied that although the gradual increase in precipitation appeared since 1980, the lake area sensitively responses to the rising temperature.

For Lake Shargiin Tsagaan (Figure 3(f), Figure 4(f)), the lake area decreased by $5.0 \mathrm{~km}^{2}$ between 1970 and 2015 (Table 3). The decrease in lake area indicates a relationship with rising temperature since 1987 and abruptly dropping precipitation since 2004 (SH in Figure 5) observed at the Sharga meteorological station (Figure 2) situating $18.2 \mathrm{~km}$ from the lake. In other words, the decrease in lake area may have begun since 1976 when precipitation fluctuated with frequencies of $\sim 5$ years and intensified since 1987 (SH in Figure 5).

Generally speaking, the lake area changes for the large lakes in the Govi region indicate a common trend in decrease between 1970 and 2014 or 2015 in relation to the continuous rise in temperature (Figure 5), not with the gradual increase in precipitation with fluctuations (Figure 5). The three largest lakes among the six lakes have lost their large areas during the past 44 or 45 years, i.e., Lakes Ulaan, Orog and Buun Tsagaan have experienced of decreases of 18.2, 95.5 and $83.2 \mathrm{~km}^{2}$, respectively (Table 3), whereas Lakes Taatsiin Tsagaan, Biger and Shargiin Tsagaan have gradually decreased by $7.9,0.5$ and $5.0 \mathrm{~km}^{2}$, respectively (Table 3). The decrease in lake area shows that the three larger lakes more directly and significantly response to the present warming (Figure 5) than the smaller three lakes. Nevertheless, the similar decreases in lake areas for the six lakes suggest that the lakes are very sensitive to increasing temperature (Figure 5) resulting in evaporation and lake shrinkage. Climatologically, data between 1975 and 2015 observed at the meteorological stations near the lakes show that the decrease in lake areas is consistent with the trends in temperature rise since 1995 and precipitation fluctuations since 1975 (Figure 5). Spatially, the large lakes in the eastern part of the Valley of Lakes are more sensitive to the rising temperature and dropping precipitation than the other lakes in the western part of the Valley of Lakes, i.e., Lakes Ulaan, Orog and Buun Tsagaan (Figure 2) have lost their large areas during the past 45 years (Table 3, Figure 4). Geomorphologically, the large lakes in the eastern part of the Valley of Lakes are surrounded by moun- 
tains elevated at 1200 - $2700 \mathrm{~m}$ a.s.l., while the lakes in western part are surrounded by higher mountains elevated at $2200-3800 \mathrm{~m}$ a.s.l. (Figure 2).

Trend in decrease of the lake areas shows that the lakes in Valley of Lakes face the challenge of the present warming, depending on local geomorphic features and climatic conditions in the lacustrine basins. The result from this study is in agreement with results by [23,24] and [25]. Davaa [23] noted that the lake area in Mongolia has reduced by $373 \mathrm{~km}^{2}$ in 1940-2000, specifically the increase in lake area for mostly large lakes located in the permafrost zone, fed by glacier melt waters, and the shrinkage and shift to the class of very small lakes for small lakes. Szumińska [24] showed a tendency for decreasing in surface area, intermittent with short episodes of resupply, observed in Lakes Buun Tsagaan and Orog during the last 40 years in the relation to climatic factors. Moreover, the number of lake change; most of the large lakes over $6 \mathrm{~km}^{2}$ in 1991 had disappeared by 2000, all of the lakes had disappeared from the Govi region by 2002, but 9 small lakes were detected again in 2006, i.e., the lakes in the Govi region showed frequent disappearance and reappearance with that average of 17.3 lakes, compared with 2.3 lakes for the other regions in Mongolia [11].

\subsection{Temperature and Precipitation-Induced Lake Area Changes}

It is shown that lakes in the Govi region are very sensitive to today's climatic warming (Figure 5 to Figure 7). The average annual temperature in Mongolia has been increasing recently [e.g., 28, 29]. The observed warming trend from 60 sites across Mongolia shows that the annual mean air temperature has risen by $2.17^{\circ} \mathrm{C}$ overall, and by $1.9^{\circ} \mathrm{C}-2.28^{\circ} \mathrm{C}$ in the high mountains and $1.6^{\circ} \mathrm{C}-1.7^{\circ} \mathrm{C}$ in the Govi desert from 1940 to 2001, and the intense drought spells in recent years are most likely due to increased temperature and decreased precipitation [28]. Figure 6 shows decrease in lake areas coinciding with temperature increases for the lakes in the Govi region. Dulamsuren et al. [29] noted the increase in trends of both annual mean maximum and minimum temperatures, and showed that the annual minimum (TXn) values of daily maximum temperatures (Figure $7(\mathrm{~d})$ ) and the annual minimum (TNn) values of daily minimum temperatures (Figure $7($ c)) have increased significantly since the year 1981, while the annual maximum (TXx) values of daily maximum temperatures (Figure 7(b)) and annual maximum (TNx) values of daily minimum temperatures (Figure 7(a)) have increased rapidly since the year 1995. These temperature increases and precipitation changes are likely to have driven observed changes in lake area, river discharge, and glacier extent [30]. For the future, climate modeling based on the greenhouse gas (GHG) A1B scenario estimates an increase in average temperature in the next 100 years of $2.6^{\circ} \mathrm{C}$ in winter and $2.4^{\circ} \mathrm{C}$ in summer [31]. This temperature rise, coupled with changes to short heavy rain, will likely increase the stress on the hydrologic regime in Mongolia.

The decreasing trend of the lake areas in the Valley of Lakes, Govi region, southern Mongolia due to increasing temperature since 1995 and fluctuating precipitation since 1975 is consistent with other results [e.g., 23, 24, 32). According to MARCC [32], the surface water flow in Mongolia increased from the mid-1970s until the 1990s and then precipitously dropped beginning in 1993 and 1994, while Davaa [23] noted that average annual river flow in Mongolia increased from the late 1970s to the early 1990s, and then decreased from 1994 to 2010. In addition, the 2003 surface water inventory indicated that in Mongolia there are 4.193 lakes and ponds, of which 760 have dried up during the last few years, whereas, the 2007 water inventory reveals that 1.181 lakes and ponds out of a total of 3.747 have dried up [32]. Kang \& Hong [25] showed the considerable seasonal and inter-annual lake area variations in Mongolia with a decrease by $-9.3 \%$ at an annual rate of $-53.7 \mathrm{~km}^{2} / \mathrm{yr}$ of total lake area from 2000 to 2011 . According to Kang et al. [11], the temporal variations of lake area showed a generally decreasing pattern in Dalanzadgad, Govi region with that the most dramatic decrease in lake area occurred between 1991 and 2000 when the lake area decreased over $80 \%$ from 47.1 to $5.9 \mathrm{~km}^{2}$, i.e., for the Dalanzadgad, the lake area change was highly correlated with temperature, but poorly with precipitation changes at both monthly $\left(\mathrm{R}^{2}=0.26\right)$ and annual $\left(\mathrm{R}^{2}\right.$ $=0.028$ ) time scales, respectively. Szumińska [24] showed that the rapid decrease in the surface areas of the Lakes Buun Tsagaan and Orog since 1995 is related to the increase in annual mean air temperature detected at the Bayankhongor meteorological station. 

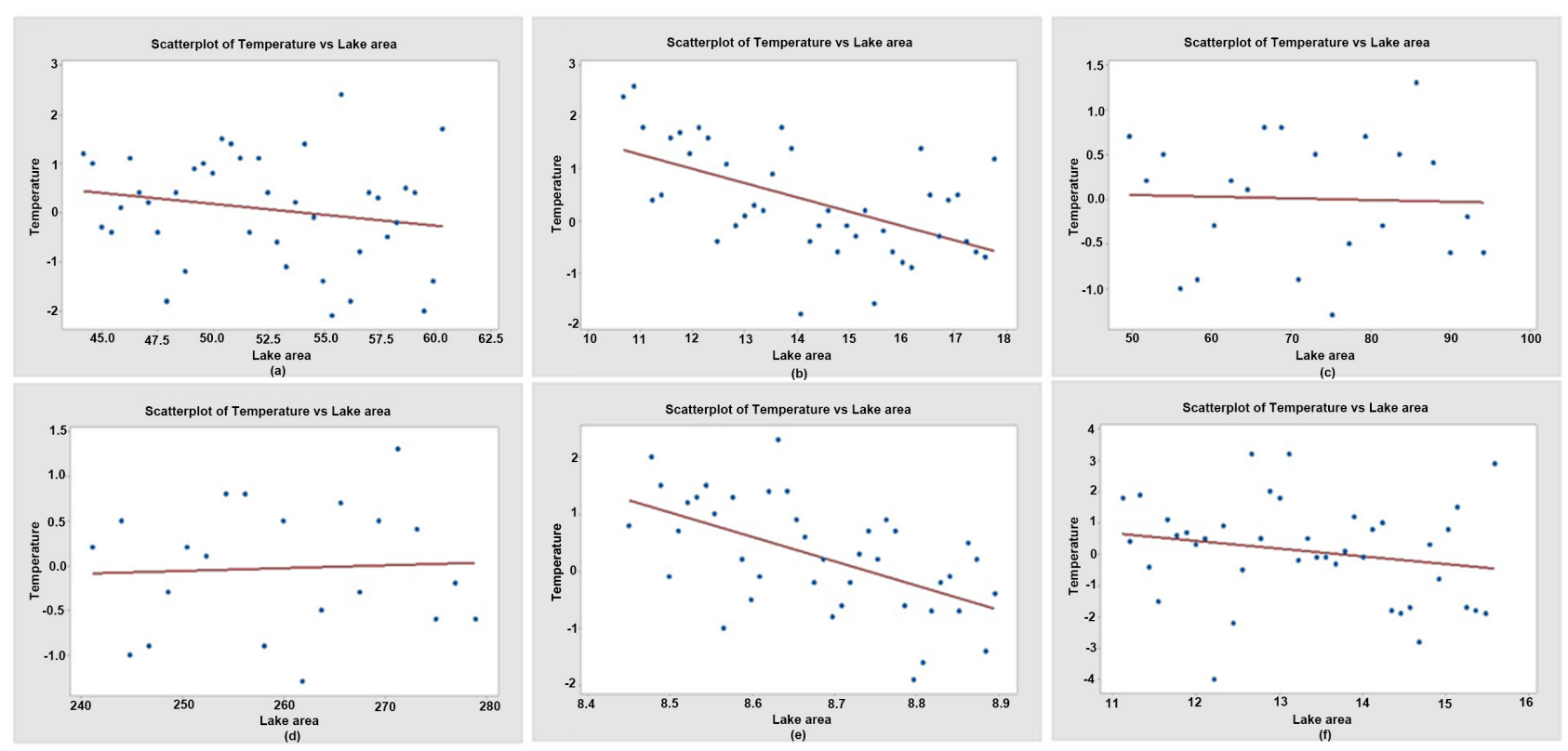

Figure 6. Relationships between temperature and lake areas for the selected lakes from in Govi region, southern Mongolia: (a) Lake Ulaan, (b) Lake Taatsiin Tsagaan, (c) Lake Orog, (d) Lake Buun Tsagaan, (e) Lake Biger, and (f) Lake Shargiin Tsagaan.

The regionality of lake area change agrees with evidence from radar-altimetry lake level data that indicate distinct but spatially different inter-annual variations of lake level for inland lakes in the Central Asia regions for the last two decades [11]. The water level fluctuations in lakes in Mongolia show that water level was generally rising from 1960 till the middle of 1990, and has been continuously falling since 1996 [23]. In northern Mongolia, the progressive reduction of the Egiin River headwaters results in the lowering of Lake Khuvsgul levels [19] where the hydrometric data of the annually averaged values show that up to $60 \mathrm{~cm} \mathrm{[33]} \mathrm{and} 80 \mathrm{~cm}$ [34] rises of the level occurred in 1973-1977 and 1982-1987 [34]. In western Mongolia, three lakes (i.e., Lakes Uvs, Khyargas and Khar) showed distinct drawdown in late 2000s [11]. The water level of the Lake Ugii located in the steppe zone dropped by $144 \mathrm{~cm}$ since 2004, while the Lake Buun Tsagaan in the Govi desert registered a drop of $603 \mathrm{~cm}$ from 1998 to 2009 [23]. Regarding ground water level fluctuations, they seem to decrease in correlation with current changes occurring in surface water resources. For instance, ground water level dropped in the Murun (forest steppe zone) by $0.55 \mathrm{~m}$, in Arvaikheer (steppe zone) by $0.3 \mathrm{~m}$ and in Ekhiin Gol (oasis in the Govi desert) by $0.50 \mathrm{~m}$ in 1997-2009 [23]. The decreasing trend in lake areas in southern Mongolia linked with local geomorphic features and climatic conditions is consistent with other results. For instance, Kang et al. [11] indicated that the regional patterns of precipitation-driven lake area changes varied considerably $\left(\mathrm{R}^{2}=0.028\right.$ 0.950), depending on the regional climate regime and hydromorphological characteristics. Kang \& Hong [25] showed a certain regional hydrology-induced significant decreasing trend in the annual mean lake area for big lakes in Govi region between 2000 and 2011.

It should be noted that lake area change depends on many factors including precipitation, evaporation, run off from the catchment, outlet discharges, groundwater balance, glaciers and permafrost $[9,10]$. A relationship between these factors and lake areas fluctuations in the Valley of Lakes would be investigated in further work.

\section{CONCLUSION}

This study shows that there are similar trends in reduction of lake areas for six large lakes in the Govi region, southern Mongolia during the recent past 44 - 45 years (from 1970 to 2014 or 2015). The decreasing 


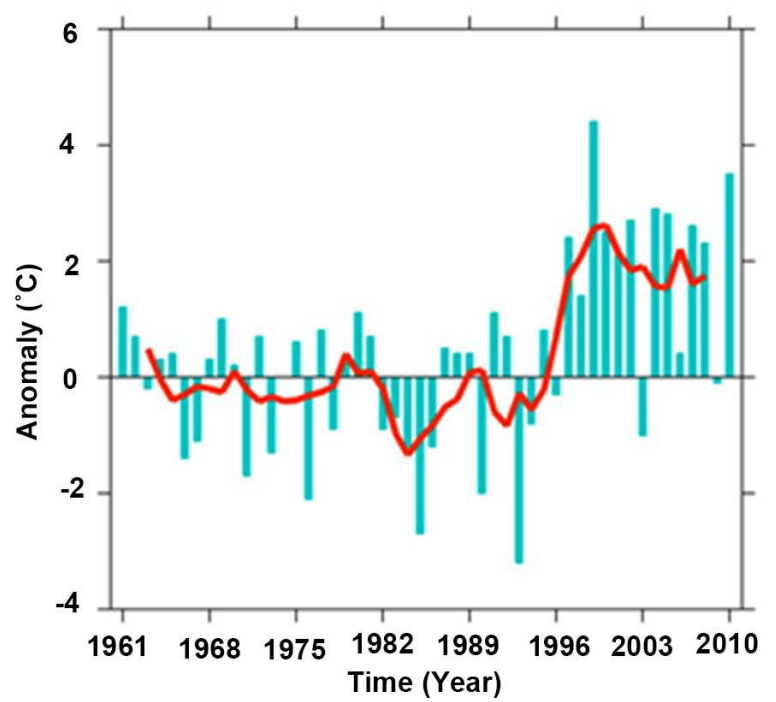

(a)

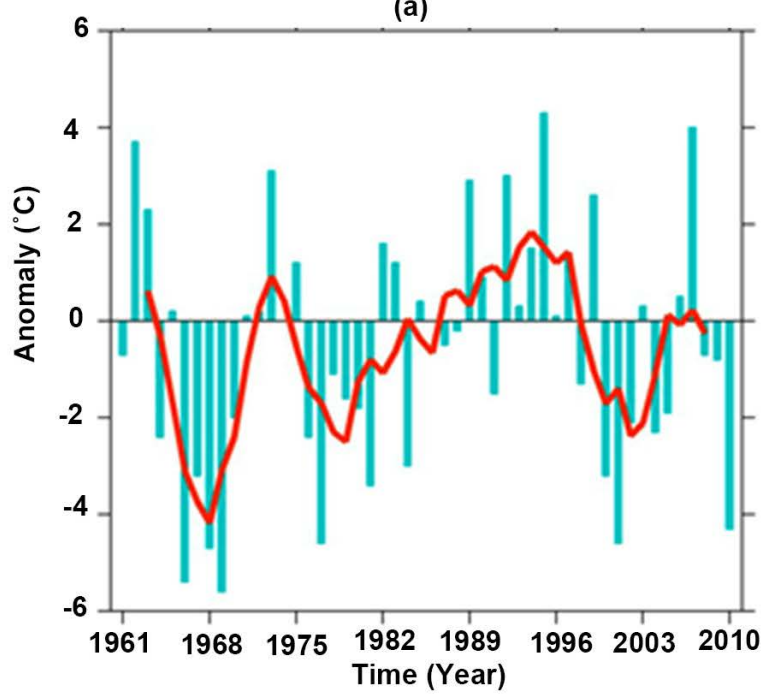

(c)

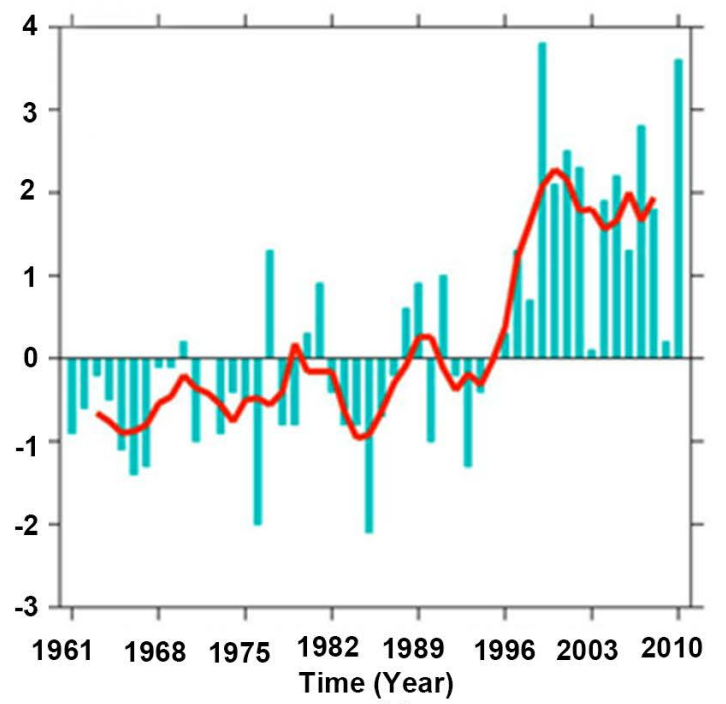

(b)

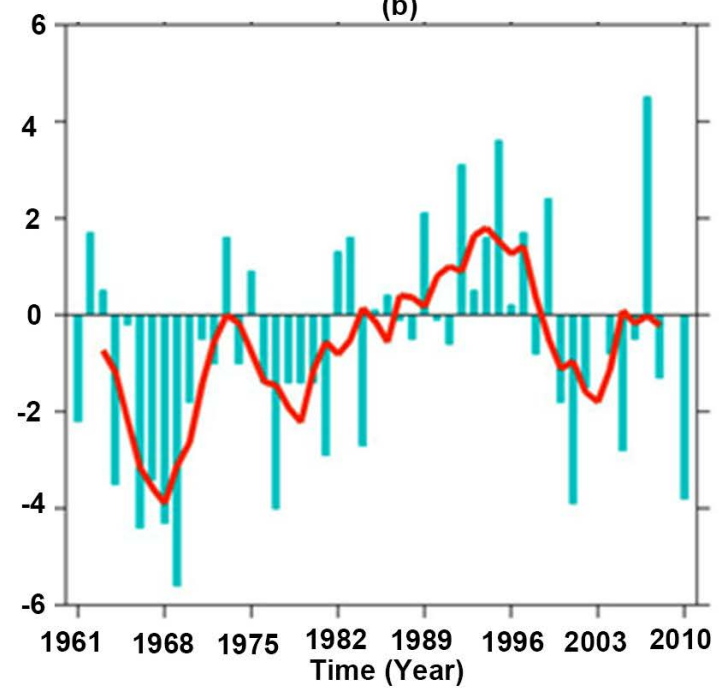

(d)

Figure 7. Anomalies of the country-averaged annual (a) Maximum Tmax (TXx), (b) Maximum Tmin (TNx), (c) Minimum Tmax (TXn), and (d) Minimum Tmin (TNn) temperatures in Mongolia in 1961-2010. The anomalies are relative to the mean values of 1971-2000. The red curves are 5-year running means. Modified from [29].

trend of the lake areas shows the a significant sensitivity of the lakes to the present climatic warming, linked with local geomorphic features and climatic conditions within the lake basins. The decreases in lake areas are consistent with the trends for increasing in temperature since 1995 and fluctuating precipitation since 1975, i.e., patterns of warming-induced reduction in lake areas are observed for the lakes in southern Mongolia. The result from the present study coincides with other studies in Mongolia. Chronological controls on sedimentary sequences from these lakes are necessary for a more complete understanding of the evolution of lake basins induced by Late Quaternary climatic changes in Mongolia in order to expand our knowledge of paleoclimatic history of Mongolia and Central Asia based on paleolakes and modern lakes.

\section{ACKNOWLEDGEMENTS}

We would like to thank the Asian Research Center, National University of Mongolia for financial support to our research under the research grant ARC2017-1253. 


\section{CONFLICTS OF INTEREST}

The authors declare no conflicts of interest regarding the publication of this paper.

\section{REFERENCES}

1. Feng, Z.D., Thompson, L.G., Mosley-Thompson, E. and Yao, T.D. (1993) Temporal Variations of Climate in China during the Past 10,000 Years. The Holocene, 3, 174-180. https://doi.org/10.1177/095968369300300210

2. D’Arrigo, R., Jacobym, G., Pederson, N., Frankm, D., Buckley, B., Nachin, B., Mijiddorj, R. and Dugarjav, C. (2000) Mongolian Tree-Rings, Temperature Sensitivity and Reconstructions of Northern Hemisphere Temperature. The Holocene, 10, 669-672. https://doi.org/10.1191/09596830094926

3. Jacoby, G., Lovelius, N., Shumilov, O., Raspopov, O., Kurbinov, J. and Frank, D. (2000) Long-Term Temperature Trends and Tree Growth in the Taymir Region of Northern Siberia. Quaternary Research, 53, 312-318.

https://doi.org/10.1006/qres.2000.2130

4. Hilbig, W. (1995) The Vegetation of Mongolia. SPB Academic Publishing, Amsterdam.

5. Gong, D.Y. and Ho, C.H. (2002) The Siberian High and Climate Change over Middle to High Latitude Asia. Theoretical and Applied Climatology, 72, 1-9. https://doi.org/10.1007/s007040200008

6. Panagiotopoulos, F., Shahgedanova, M., Hannachi, A. and Stephenson, D.B. (2005) Observed Trends and Teleconnections of the Siberian High: A Recently Declining Center of Action. Journal of Climate, 18, 1411-1422. https://doi.org/10.1175/JCLI3352.1

7. Visbeck, M. (2002) The Ocean's Role in Atlantic Climate Variability. Science, 297, 2223-2224. https://doi.org/10.1126/science.1074029

8. An, C.B., Chen, F.H. and Barton, L. (2008) Holocene Environmental Changes in Mongolia: A Review. Global and Planetary Change, 63, 283-289. https://doi.org/10.1016/j.gloplacha.2008.03.007

9. Brown, A.G. (1995) Vegetation and Lake-Level Change. In: Gregory, K.J., Starkel, L. and Baker, V.R., Eds., Global Continental Palaeohydrology, John Wiley \& Sons, Hoboken, 131-150.

10. Komatsu, G., Brantingham, P.J., Olsen, J.W. and Baker, V.R. (2001) Paleoshoreline Geomorphology of Boon Tsagaan Nuur, Tsagaan Nuur and Orog Nuur: The Valley of Lakes, Mongolia. Geomorphology, 39, 83-98. https://doi.org/10.1016/S0169-555X(00)00095-7

11. Kang, S., Lee, G., Togtokh, C. and Jang, K. (2015) Characterizing Regional Precipitation-Driven Lake Area Change in Mongolia. Journal of Arid Land, 7, 146-158. https://doi.org/10.1007/s40333-014-0081-x

12. Dorofeyuk, N.I. and Tarasov, P.E. (1998) Vegetation and Lake Levels of Northern Mongolia Since 12,500 yr B.P. Based on the Pollen and Diatom Records. Stratigraphy and Geology Correlation, 6, 70-83.

13. Grunert, J., Lehmkuhl, F. and Walther, M. (2000) Paleoclimatic Evolution of the Uvs Nuur Basin and Adjacent Areas (Western Mongolia). Quaternary International, 65/66, 171-192. https://doi.org/10.1016/S1040-6182(99)00043-9

14. Peck, J.A., Khosbayar, P., Fowell, S.J., Pearce, R.B., Ariunbileg, S., Hansen, B.C.S. and Soninkhishig, N. (2002) Mid to Late Holocene Climate Change in North Central Mongolia as Recorded in the Sediments of Lake Telmen. Palaeogeography, Palaeoclimatology, Palaeoecology, 183, 135-153.

https://doi.org/10.1016/S0031-0182(01)00465-5

15. Krivonogov, S.K., Sheinkman, V.S. and Mistruykov, A.A. (2005) Stages in the Development of the Darhad Dammed Lake (Northern Mongolia) during the Late Pleistocene and Holocene. Quaternary International, 136, 83-94. https://doi.org/10.1016/j.quaint.2004.11.010

16. Prokopenko, A.A., Khursevich, G.K., Bezrukova, E.V., Kuzmin, M.I., Boes, X., Williams, D.F., Fedenya, S.A., 
Kulagina, N.V., Letunova, P.P. and Abzaeva, A.A. (2007) Paleoenvironmental Proxy Records from Lake Hovsgol, Mongolia, and a Synthesis of Holocene Climate Change in the Lake Baikal Watershed. Quaternary Research, 68, 2-17. https://doi.org/10.1016/j.yqres.2007.03.008

17. Gillespie, A.R., Burke, R.M., Komatsu, G. and Bayasgalan, A. (2008) Late Pleistocene Glaciers in Darhad Basin, Northern Mongolia. Quaternary Research, 69, 169-187. https://doi.org/10.1016/j.yqres.2008.01.001

18. Wang, W., Ma, Y.Z., Feng, Z.D., Narantsetseg, Ts., Liu, K.B. and Zhai, X.W. (2011) A Prolonged Dry Mid-Holoncene Climate Revealed by Pollen and Diatom Records from Lake Ugii Nuur in Central Mongolia. Quaternary International, 229, 74-83. https://doi.org/10.1016/j.quaint.2010.06.005

19. Orkhonselenge, A., Krivonogov, S.K., Mino, K., Kashiwaya, K., Safonova, I.Y., Yamamoto, M., Kashima, K., Nakamura, T. and Kim, J.Y. (2013) Holocene Sedimentary Records from Lake Borsog, Eastern Shore of Lake Khuvsgul, Mongolia, and Their Paleoenvironmental Implications. Quaternary International, 290-291, 95-109. https://doi.org/10.1016/j.quaint.2012.03.041

20. Klinge, M. and Lehmkuhl, F. (2013) Geomorphology of the Tsetseg Nuur Basin, Mongolian Altai-Lake Development, Fluvial Sedimentation and Aeolian Transport in a Semi-Arid Environment. Journal of Maps, 9, 361-366. https://doi.org/10.1080/17445647.2013.783513

21. Tserensodnom, J. (1971) Lakes of Mongolia. State Publishing, Ulaanbaatar. (In Mongolian)

22. National Atlas of the Mongolian People's Republic (1990) Ulaanbaatar and Moscow: Academy of Sciences of Mongolian and Academy of Sciences of USSR. (In Russian)

23. Davaa, G. (2010) Climate Change Impacts on Water Resources in Mongolia. In: Proceedings of Consultative Meeting on Integration of Climate Change Adaptation into Sustainable Development in Mongolia, Institute for Global Environmental Strategies (IGES), 30-36.

24. Szumińska, D. (2016) Changes in Surface Area of the Böön tsagaan and Orog Lakes (Mongolia, Valley of the Lakes, 1974-2013) Compared to Climate and Permafrost Changes. Sedimentary Geology, 340, 62-73. https://doi.org/10.1016/j.sedgeo.2016.03.002

25. Kang, S. and Hong, S.Y. (2016) Assessing Seasonal and Inter-Annual Variations of Lake Surface Areas in Mongolia during 2000-2011 Using Minimum Composite MODIS NDVI. PLoS ONE, 11, e0151395. https://doi.org/10.1371/journal.pone.0151395

26. Andrén, E., Klimaschewski, A., Self, A.E., Amour, N.S., Andreev, A.A., Bennett, K.D., Conley, D.J., Edwards, T.W.D., Solovieva, N. and Hammarlund, D. (2015) Holocene Climate and Environmental Change in North-Eastern Kamchatka (Russian Far East), Inferred from a Multi-Proxy Study of Lake Sediments. Global and Planetary Change, 134, 41-54. https://doi.org/10.1016/j.gloplacha.2015.02.013

27. Komatsu, G., Baker, V.R., Arzhannikov, S., Gallagher, R., Arzhannikova, A.V., Murana, A. and Oguchi, T. (2016) Catastrophic Flooding, Palaeolakes and Late Quaternary Drainage Reorganization in Northern Eurasia. International Geology Review, 58, 1693-1722. https://doi.org/10.1080/00206814.2015.1048314

28. Batima, P., Natsagdorj, L., Gomboluudev, P. and Erdenetsetseg, B. (2005) Observed Climate Change in Mongolia. AIACC Working Paper, Ulaanbaatar, 12.

29. Dulamsuren, D., Kim, J.P., Chun, J.A. and Lee, W.S. (2015) Long-Term Trends in Daily Temperature Extremes over Mongolia. Weather and Climate Extremes, 8, 26-33. https://doi.org/10.1016/j.wace.2014.11.003

30. IGES (Institute for Global Environmental Strategies) (2010) Proceedings of Consultative Meeting on Integration of Climate Change Adaptation into Sustainable Development in Mongolia. IGES Conference Report, Ulaanbaatar.

31. Sarantuya, C. and Natsagdorj, L. (2010) Climate Change in Mongolia. In: Proceedings of Consultative Meeting on Integration of Climate Change Adaptation into Sustainable Development in Mongolia, Institute for Global 
Environmental Strategies (IGES), 23-28.

32. MARCC (Mongolia: Assessment Report on Climate Change) (2009) Ministry of Environment, Nature and Tourism, Mongolia.

33. Kumagai, M., Urabe, J., Goulden, C.E., Soninkhishig, N., Hadbaatar, D., Tsujimura, S., Hayami, Y., Sekino, T. and Maruo, M. (2006) Recent Rise in Water Level at Lake Hovsgol, Mongolia. In: Goulden, C.E., Sitnikova, T., Gelhaus, J. and Bazartseren, B., Eds., The Geology, Biodiversity and Ecology of Lake Hovsgol (Mongolia), Backhuys Publishers, Leiden, 77-92.

34. Batsukh, A., Shumeev, V.P., Cherkasov, A.E. and Samarin, A.V. (1976) Surface Water and the Water Balance of the Khubsugul. In: Natural Conditions and Resources of Trans-Khubsugulia in the MPR, Nedra, 185-206. (In Russian). 